\title{
Meiotic analysis in induced tetraploids of Brachiaria decumbens Stapf
}

\author{
Carine Simioni ${ }^{1 *}$ and Cacilda Borges do Valle ${ }^{2}$
}

Received 4 May 2010

Accepted 4 August 2010

\begin{abstract}
The meiotic behavior of three tetraploid plants $(2 n=4 x=36)$ originated from somatic chromosome duplication of sexually reproducing diploid plants of Brachiaria decumbens was evaluated. All the analyzed plants presented abnormalities related to polyploidy, such as irregular chromosome segregation, leading to precocious chromosome migration to the poles and micronuclei during both meiotic divisions. However, the abnormalities observed did not compromise the meiotic products which were characterized by regular tetrads and satisfactory pollen fertility varying from 61.36 to $64.86 \%$. Chromosomes paired mostly as bivalents in diakinesis but univalents to tetravalents were also observed. These studies contributed to the choice of compatible fertile sexual genitors to be crossed to natural tetraploid apomicts in the B. decumbens by identifying abnormalities and verifying pollen fertility. Intraespecific crosses should reduce sterility in the hybrids produced in the breeding program of Brachiaria, a problem observed with the interspecific hybrids produced so far.
\end{abstract}

Key words: Brachiaria, chromosome duplication, intraspecific crosses, meiotic behavior, plant breeding.

\section{INTRODUCTION}

Brachiaria (Trin.) Griseb, a tropical forage grass genus of mainly African origin, has species that are widely used in cultivated pastures in Latin America (Renvoize et al. 1996). However, the diversity of pastures is dangerously restricted to a few cultivars, especially in the case of $B$. decumbens, with a single cultivar spread from México to all of South America. These reproduce asexually through apomixis (Valle and Savidan 1996) thus embryos are parthenogenetic and progenies are identical to the motherplant (Dusi and Williemse 1999). This lack of diversity leads to homogeneous pastures, which is advantageous for animal management but represent a serious risk when planted over wide expanses of land. Superior Brachiaria cultivars are in great demand to diversify pastures with varieties well adapted to soil and climate, resistance to pests and persistence under grazing (Valle et al. 2008, Valle and Pagliarini 2009).

Diploid accessions of obligate sexual reproduction - one of B. brizantha and 20 of B. decumbens were identified upon characterization of the collection (Valle 1990, Penteado et al. 2000). These may be used in crosses with apomictic cultivars once the ploidy barrier is overcome. Thus, doubling the chromosomes of sexual diploids $(2 \mathrm{x})$ was the easiest way to produce a $4 \mathrm{x}$ sexual plant to use as the female parent in sexual $x$ apomictic crosses (Valle 1990). This strategy resulted in widening genetic variability across inter and intraspecific hybrids thus allowing the selection of new genotypes which may be conserved by

\footnotetext{
${ }^{1}$ Universidade Federal do Rio Grande do Sul (UFRGS), Departamento de Plantas Forrageiras e Agrometeorologia, Avenida Bento Gonçalves 7712, 91.501-970, Porto Alegre, RS, Brazil. *E-mail: carine.simioni@ufrgs.br

${ }^{2}$ Embrapa Gado de Corte, BR 262, CP 154, 79.002-970, Campo Grande, MS, Brazil
} 
apomixis and could combine nutritive value and resistance to spittlebugs, especially in the case of $B$. decumbens (Valle et al. 2008).

Chromosome duplication of sexual and diploid accessions of $B$. decumbens was carried out at Embrapa Beef Cattle Research Center, Campo Grande, Brazil, between 2004 and 2007. Effectiveness of polyploidization was low due to problems in extraction and in vitro meristem culture, which demanded time and large quantities of plant material. In this work, only $3.9 \%$ of the regenerated and examined plants resulted in tetraploids (Valle et al. 2008, Simioni and Valle 2009). This paper describes the meiotic behavior and pollen viability of three of the artificially tetraploidized plants of sexual reproduction from that experimentation. The objective of this detailed analysis was to identify problem genotypes which need to be discarded as genitors in the breeding program.

\section{MATERIAL AND METHODS}

The three plants (cD24-2, cD24-27 and cD24-45) used for meiotic analyses were obtained by chromosome doubling of a diploid sexual accession of B. decumbens, named D24, by colchicine treatment of basal segments of in vitro grown plantlets. Ploidy levels and complete euploidy was confirmed by chromosome counting in root tips. The mode of reproduction was confirmed as sexual through analysis of embryo-sacs (Valle et al. 2008, Simioni and Valle 2009), using interference contrast microscopy on methylsalycilate cleared ovules as established by Young et al. (1979).

For meiotic studies, young inflorescences still folded in the flag leaf were collected from the three tetraploid plants, then fixed in a solution containing absolute ethanol: acetic acid (3:1) for 24 hours, transferred to $70 \%$ ethyl alcohol and stored under refrigeration (Araújo et al. 2005). Microsporocytes were prepared by squashing and staining with $1 \%$ propionic carmine and analyzed under light microscopy.

All meiotic phases were evaluated and abnormalities recorded. Most of the gametic chromosome counts were performed in cells at diakinesis and metaphase I, since at these stages chromosome pairing is clearly observed. A minimum of 20 cells in diakinesis were analyzed.

Pollen fertility was estimated in fresh dehiscent anthers. About 1500 mature pollen grains per plant were evaluated. Pollen fertility was determined by the staining with $1 \%$ propionic carmine: full, stained grains were classified as fertile and non-stained or weakly stained grains were considered sterile (Simioni et al. 2004, Simioni et al. 2006).

\section{RESULTS AND DISCUSSION}

Chromosome associations at diakinesis confirmed the polyploid condition $(2 n=4 x=36)$ in the three plants evaluated. Meiotic behavior, mainly in meiosis I, was typical of polyploids, with chromosomes associating as univalents, bivalents and quadrivalents, with the prevalence of bivalent configurations (Table 1, Figure 1a).

The three plants underwent somatic duplication, thus becoming autotetraploid organisms possessing a combination of two genetically similar genomes (homologous). In such cases, the chromosome behavior at meiosis is expected to be random or not in any preferential form (polyssomic inheritance) (Albinic et al. 2006), with a tendency to form multivalents (Ramsey and Schemske 2002). However, the predominance of bivalent associations suggests a genetic control of chromosome pairing such as has been recognized in artificially induced autotetraploids of Trifolium riograndense (Schifino and Moraes-Fernandes 1986, 1987), of B. brizantha (Araújo et al. 2005), and of B. ruziziensis (Risso-Pascotto et al. 2005). In 20 accessions of natural tetraploid $B$. nigropedata $(2 \mathrm{n}=$ $4 \mathrm{x}=36$ ), bivalent associations also predominated in diakinesis, suggesting that its origin was possibly as a segmental allopolyploid (Utsunomiya et al. 2005). In contrast, Caetano et al. (2006), studying autotetraploid Panicum maximum cv Tanzânia $(2 \mathrm{n}=4 \mathrm{x}=36)$, found 99 cells presented multivalent associations at diakinesis, with a predominance of tetravalents among the 109 diakinesis analyzed. In B. decumbens cv. Basilisk $(2 \mathrm{n}=4 \mathrm{x}=36)$, the meiotic process was typical of polyploids with multiple chromosome associations (Junqueira-Filho et al. 2003). Of the interspecific hybrids between the induced tetraploid sexual accessions of $B$. ruziziensis and the natural and apomictic tetraploid accessions of $B$. brizantha $(2 \mathrm{n}=4 \mathrm{x}=$ $36)$ and $B$. decumbens $(2 n=4 x=36)$, only $6.3 \%$ of the microsporocytes paired as 18 bivalents, explaining the reduction in pollen viability of these hybrids (Lutts et al. 1991, Lutts et al. 1994).

From a total of 5502 microsporocytes analyzed in the three duplicated plants of this experiment, 1053 presented irregularities from prophase I until meiotic products, representing $19.14 \%$ of the total cells analyzed (Table 2). The most frequent abnormalities in the two 
Meiotic analysis in induced tetraploids of Brachiaria decumbens Stapf

Table 1. Meiotic chromosome configurations at diakinesis phase (prophase I) of three tetraploid plants of Brachiaria

\begin{tabular}{|c|c|c|c|c|c|c|}
\hline \multirow{2}{*}{ Plant number } & \multirow{2}{*}{ Chromosome number } & \multirow{2}{*}{ Nr. of cells analyzed } & \multicolumn{4}{|c|}{ Mean nr. of observed associations (per cell) (range) } \\
\hline & & & $\mathbf{I}$ & II & III & IV \\
\hline cD24-2 & 36 & 52 & $\begin{array}{l}0.11 \\
(0-2)\end{array}$ & $\begin{array}{c}16.92 \\
(12-18)\end{array}$ & $\begin{array}{c}0.11 \\
(0-2)\end{array}$ & $\begin{array}{l}0.42 \\
(0-3)\end{array}$ \\
\hline cD24-27 & 36 & 30 & $\begin{array}{c}0.77 \\
(0-10)\end{array}$ & $\begin{array}{l}15.26 \\
(8-18)\end{array}$ & $\begin{array}{c}0.5 \\
(0-3)\end{array}$ & $\begin{array}{l}0.73 \\
(0-3)\end{array}$ \\
\hline cD24-45 & 36 & 70 & $\begin{array}{l}0.19 \\
(0-2)\end{array}$ & $\begin{array}{c}16.2 \\
(8-18)\end{array}$ & $\begin{array}{l}0.13 \\
(0-2)\end{array}$ & $\begin{array}{l}0.76 \\
(0-4)\end{array}$ \\
\hline
\end{tabular}

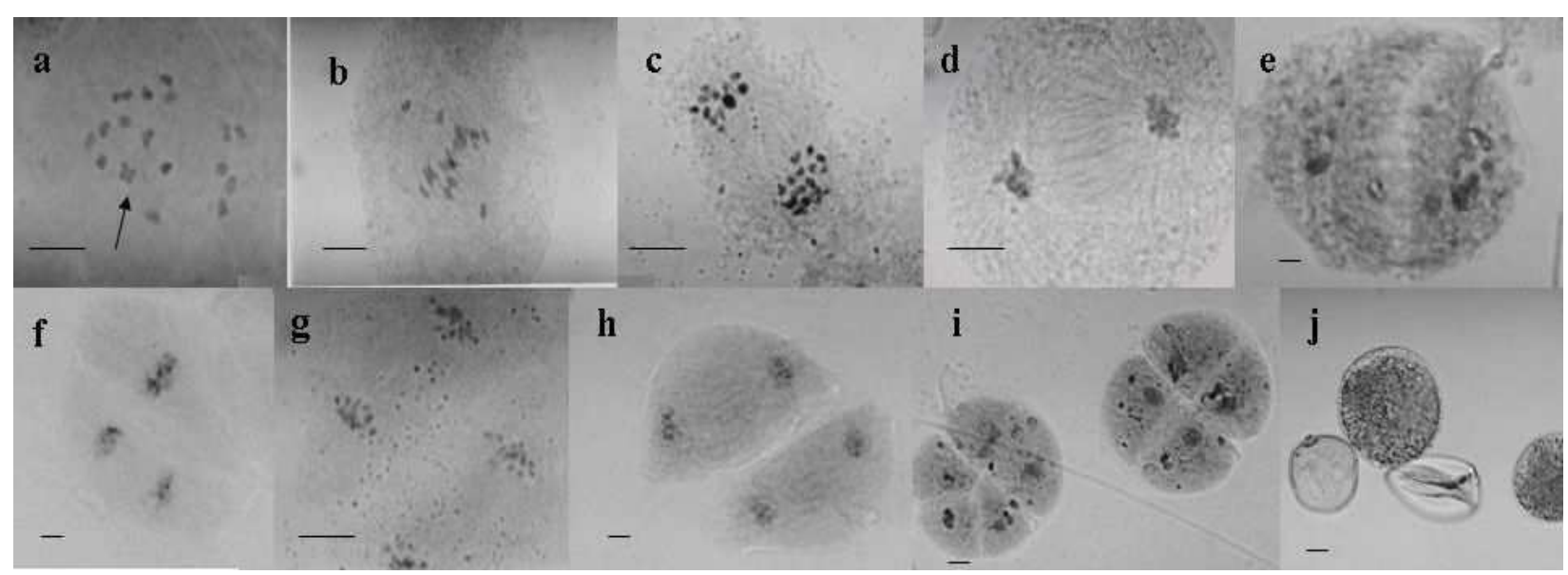

Figure 1. Meiotic aspects of the tetraploidized accession D24 of B. decumbens. a) Microsporocytes in diakinesis (plant cD24-2) (note the prevalence of bivalent associations; tetravalent association (arrow); b) metaphase I with precocious migration (plant cD24- 2); c) normal anaphase I (plant cD24-2); d) normal telophase I (plant cD24- 45); e) normal prophase II (cD24-45); f) metaphase II with asynchrony (cD24- 45); g) normal anaphase II (cD24-27); h) normal telophase II (cD24-2); i) Microspores (tetrads and polyads with micronuclei) (cD24-2); j) fertile pollen grains (stained) and sterile (not stained), plant D24-27. Scale Bar $=10 \mathrm{~mm}$.

meiotic divisions were those related to chromosome segregation. In the first division, some precocious chromosome migration to the poles at metaphase (Figure 1b), laggards and bridges at anaphase were observed. Only a few meiocytes displayed some abnormalities in the second division: asynchrony in metaphase (Figure 1f) was the most common, but did not compromise the final meiotic product because all cells completed meiosis in time to form a regular tetrad and eventually forming normal pollen grains (Risso-Pascotto et al. 2004).

The final product of meiosis was characterized by normal tetrads, but a few dyads, triads, polyads and tetrads with micronuclei (Figures 1i, 1j) were also observed. Failure of cytokinesis in the first and second meiotic division leading to dyad and triad formation was also reported for Brachiaria (Valle and Pagliarini 2009). This phenomenon occurred in these plants, but in low frequencies (data not shown in the Table 2), thus not compromising the predominance of tetrads.

A mean percentage of meiotic abnormalities for each plant were: $18.4 \%$ (plant cD24-2), $20.9 \%$ (plant cD24-27) and $18.2 \%$ (plant cD24-45), whereas the total number of cells evaluated (Table 2), indicating that such abnormalities occurred in similar frequencies in these induced polyploids.

Pollen viability was estimated to be $64.86 \%$ for plant cD24-2, 61.36\% for plant cD24-27 and $63.25 \%$ for plant cD24-45 (Table 3, Figure 1j). This index was considered high for treated plants artificially induced to chromosomal duplication. Since around $63.16 \%$ of pollen was viability, the progenies of these might be evaluated in order to select promising genotypes.

The levels of viable pollen grains in these tetraploid plants (average $63.16 \%$ ) are similar to those observed by Risso-Pascotto et al. (2004), in tetraploid hybrids from the 
C Simioni and CB Valle

Table 2. Meiotic abnormalities recorded in three tetraploidized plants of accession D24 of B. decumbens

\begin{tabular}{|c|c|c|c|c|}
\hline Plant number & Phases & Nr. of analyzed cells & $\begin{array}{c}\text { Nr. of abnormal cells } \\
(\%)\end{array}$ & $\begin{array}{l}\text { Main abnormalities } \\
\text { (nr. of cells and \%) }\end{array}$ \\
\hline \multirow{10}{*}{ cD24-2 } & Prophase I (diakinesis) & 52 & $24(46.2)$ & $\begin{array}{l}\text { Multiple chromosome associations: } \\
24(46.2)\end{array}$ \\
\hline & Metaphase I & 351 & $156(44.4)$ & Precocious migration: 99 (28.2) \\
\hline & Anaphase I & 202 & $33(16.3)$ & $\begin{array}{l}\text { Bridges: } 17(8.4) \\
\text { Laggards: } 16(7.9)\end{array}$ \\
\hline & Telophase I & 241 & $6(2.5)$ & Laggards: $6(2.5)$ \\
\hline & Prophase II & 222 & $7(3.2)$ & Abnormal cytokinesis: 5 (2.2) \\
\hline & Metaphase II & 148 & $54(36.5)$ & $\begin{array}{l}\text { Asynchrony: } 14(9.5) \\
\text { Precocious migration: } 13(8.8)\end{array}$ \\
\hline & Anaphase II & 129 & $22(17.1)$ & Asynchrony: $12(9.3)$ \\
\hline & Telophase II & 82 & $10(12.2)$ & $\begin{array}{l}\text { Asynchrony: } 5 \text { (6.1) } \\
\text { Absence of cytokinesis: } 3 \text { (3.6) } \\
\text { Micronuclei: } 4(0.8)\end{array}$ \\
\hline & Meiotic product & 494 & $42(8.5)$ & Polyads: $27(5.5)$ \\
\hline & & & & Triads: $8(1.6)$ \\
\hline Total nr. of cells & & 1921 & $354(18.4)$ & \\
\hline \multirow{10}{*}{ cD24-27 } & Prophase I (diakinesis) & 30 & $20(66.7)$ & $\begin{array}{l}\text { Multiple chromosome associations: } \\
20(66.7)\end{array}$ \\
\hline & Metaphase I & 315 & $72(22.8)$ & Precocious migration: $60(19.0)$ \\
\hline & Anaphase I & 129 & $9(7.0)$ & Laggards: $8(6.2)$ \\
\hline & Telophase I & 176 & $9(4.5)$ & Aderence bridges: 7 (4.0) \\
\hline & Prophase II & 142 & $5(3.5)$ & Laggards: 5 (3.5) \\
\hline & Metaphase II & 226 & $106(46.9)$ & $\begin{array}{l}\text { Precocious migration: } 43(19.0) \\
\text { Asynchrony: } 40(17.7) \\
\text { Bridges: } 26(11.9)\end{array}$ \\
\hline & Anaphase II & 219 & $77(35.2)$ & Laggards: 24 (10.9) \\
\hline & & & & Asynchrony: 24 (10.9) \\
\hline & Telophase II & 168 & $4(2.4)$ & Bridges: $2(1.2)$ \\
\hline & Meiotic product & 313 & $58(18.5)$ & $\begin{array}{l}\text { Micronuclei: } 8(2.5) \\
\text { Triads: } 46(14.7)\end{array}$ \\
\hline Total nr. of cells & & 1718 & $360(20.9)$ & \\
\hline \multirow{9}{*}{ cD24-45 } & Prophase I (diakinesis) & 70 & $42(60.0)$ & $\begin{array}{l}\text { Multiple chromosome associations: } \\
42(60.0)\end{array}$ \\
\hline & Metaphase I & 330 & $90(27.3)$ & Precocious migration: 68 (20.6) \\
\hline & Anaphase I & 206 & $29(14.1)$ & Laggards: 18 (8.7) \\
\hline & Telophase I & 240 & $13(5.4)$ & $\begin{array}{l}\text { Bridges: } 7(2.9) \\
\text { Laggards: } 6(2.5)\end{array}$ \\
\hline & Prophase II & 225 & - & - \\
\hline & Metaphase II & 226 & $75(33.2)$ & $\begin{array}{l}\text { Asynchrony: } 33 \text { (14.6) } \\
\text { Precocious migration: } 19(8.4)\end{array}$ \\
\hline & Anaphase II & 132 & $49(37.1)$ & $\begin{array}{l}\text { Asynchrony: } 20(15.1) \\
\text { Bridges: } 17(12.9)\end{array}$ \\
\hline & Telophase II & 153 & $12(7.8)$ & Asynchrony: 7 (4.6) \\
\hline & Meiotic product & 281 & $29(10.32)$ & $\begin{array}{l}\text { Micronuclei: } 7(2.5) \\
\text { Diads: } 9(3.2) \\
\text { Triads: } 6(2.1)\end{array}$ \\
\hline Total n r.of cells & & 1863 & $339(18.2)$ & \\
\hline
\end{tabular}

cross between $B$. ruziziensis $(2 \mathrm{n}=4 \mathrm{x}=36)$ and $B$. brizantha $(2 \mathrm{n}=4 \mathrm{x}=36)$, where pollen viability reached $52.76 \%$.

In B. brizantha, tetraploid and hexaploid accessions displayed irregular chromosome segregation resulting in the formation of micronuclei in the tetrads (MendesBonato et al. 2002a). In induced autotetraploids of $B$. ruziziensis, irregular chromosome segregation in the two meiotic divisions led to the development of polyads as the final meiotic product and pollen sterility reached 63.38\% (Risso-Pascotto et al. 2005). In the natural tetraploid B. decumbens cv Basilisk, many cells with precocious chromosome migration to the poles at metaphase I and 
Table 3. Pollen viability $(\%)$ of three tetraploidized plants of accession D24 of B. decumbens

\begin{tabular}{cccc}
\hline $\begin{array}{c}\text { Plant } \\
\text { number }\end{array}$ & $\begin{array}{c}\text { Viable pollen } \\
(\%)\end{array}$ & $\begin{array}{c}\text { Pollen sterility } \\
(\%)\end{array}$ & $\begin{array}{c}\text { Nr. of pollen } \\
\text { grains analyzed }\end{array}$ \\
\hline $\mathrm{cD} 24-2$ & 64.86 & 35.14 & 629 \\
$\mathrm{cD} 24-27$ & 61.36 & 38.64 & 1030 \\
$\mathrm{cD} 24-45$ & 63.25 & 36.75 & 928 \\
\hline Mean & 63.16 & 36.84 & \\
\hline
\end{tabular}

laggards at anaphase gave rise to micronuclei in telophase I generating a high frequency of abnormal products in meiosis (Mendes-Bonato et al. 2002b). Some irregularities in Brachiaria were never before observed in other plants. Among the irregularities, abnormal chromosome segregation, desynapsis, chromosome stickiness, fusional syncytes, multipolar spindles and chromosome transfer among microsporocytes were reported (Mendes-Bonato et al. 2001a, Mendes-Bonato et al. 2001b, Risso-Pascotto et al. 2003b, 2005, Risso-Pascotto et al. 2003c, Utsunomiya et al. 2005, Boldrini et al. 2006), and some of them caused partial or total pollen sterility, compromising the use of those genotypes in breeding programs. In several meiotic studies carried out in accessions of Brachiaria, the described meiotic abnormalities have been attributed to mutations (Risso-Pascotto et al. 2003a).

In autotetraploid Panicum maximum cv Tanzânia, meiotic abnormalities occurred in a significant frequency. The most common were precocious migration and laggard chromosomes at metaphase and anaphase, respectively; micronuclei in telophase, tetrads with unbalanced microspores and microcytes were also quite frequent. Cell fusion in different phases of the meiotic process was also observed (Caetano et al. 2006).

Cytological analyses like the ones presented here are extremely important tools in the breeding programs in order to select compatible and fertile genitors, both by determining the level of ploidy and the absence of meiotic abnormalities that could compromise the viability of the gametes.

All three artificially polyploidized plants of $B$. decumbens, accession D24, displayed some chromosome abnormalities but those did not impair gamete fertility. The frequencies of abnormalities varied both with the genotypes evaluated and the phase of meiosis analyzed. Pollen sterility remained below $37 \%$ in all three genotypes. Therefore, all three could be used as female or male genitors both in a sexual crossing block to recover more fertile progenies, or in crosses with apomictic $B$. decumbens $\mathrm{cv}$. Basilisk to recover sexual and apomictic hybrids. These intraspecific crosses were never before attempted in $B$. decumbens. Hybrids of these duplicated plants crossed to natural apomicts should result in a progeny segregating for sexual and apomictic plants in a 1: 1 proportion, as previously reported for interspecific hybrids of Brachiaria (Valle and Savidan 1996). Whereas sexual hybrids may be used in further crosses in the breeding program, the apomictic ones can enter agronomic performance in field trials. Those displaying superior agronomic traits are immediate candidates as new cultivars to promote pasture diversification with increased productivity, insect resistance and improved nutritive value. Polyploidization of $B$. decumbens is thus a major breakthrough in the breeding of this species of indisputable significance to animal production in the tropics.

\section{ACKNOWLEDGMENTS}

The authors thank the National Center for Research on Beef Cattle (Embrapa Beef Cattle, Brazil), the National Council for Scientific and Technological Development (CNPq, Brazil), the State Foundation of Science and Technology (Fundect, MS, Brazil), the Association for the Promotion of Tropical Forage Breeding (UNIPASTO) and the Foundation for Support of Agricultural Research (Fundapam), Brazil, for the financial support. 


\title{
Análise meiótica em tetraplóides induzidos de Brachiaria decumbens Stapf
}

\begin{abstract}
RESUMO - $O$ comportamento meiótico de três plantas tetraplóides $(2 n=4 x=36)$ originadas de duplicação cromossômica somática de uma planta diplóide de reprodução sexual de Brachiaria decumbens foi avaliado. Todas as plantas analisadas apresentaram anormalidades relacionadas à poliploidia, tais como segregação cromossômica irregular, levando à migração precoce dos cromossomos para os polos e formação de micronúcleos durante as duas divisões meióticas. Entretanto, as anormalidades observadas não comprometeram os produtos meióticos, que foram caracterizados por tétrades regulares e satisfatória fertilidade dos grãos de pólen, que variou de 61,36 a 64,86\%. Os cromossomos parearam principalmente como bivalentes na diacinese, mas univalentes até tetravalentes também foram observados. Estes estudos contribuíram para a escolha de genitores sexuais férteis e compatíveis para cruzamento com apomíticos naturais de B. decumbens, identificando anormalidades e conferindo a viabilidade do pólen. Com cruzamentos intraespecíficos, espera-se reduzir a esterilidade nos híbridos produzidos no programa de melhoramento, problema observado nos híbridos interespecíficos obtidos até então.
\end{abstract}

Palavras-chave: Brachiaria, comportamento meiótico, cruzamentos intraespecíficos, duplicação cromossômica, melhoramento vegetal.

\section{REFERENCES}

Albinic JC, Creste S and Figueira A (2006) Uso de marcadores moleculares no mapeamento genético visando o melhoramento da cana-de-açúcar. Biotecnologia, Ciência e Desenvolvimento 36: $82-91$.

Araújo ACG, Nóbrega JM, Pozzobon MT and Carneiro VTC (2005) Evidence of sexuality in induced tetraploids of Brachiaria brizantha (Poaceae). Euphytica 144: 39-50.

Boldrini KR, Pagliarini MS and Valle CB (2006) Cell fusion and cytomixis during microsporogenesis in Brachiaria humidicola (Poaceae). South African Journal of Botany 72: 478-481.

Caetano CM, Bonfá BRCN and Canto MW (2006) Autotetraploidia e número cromossômico em uma cultivar de Panicum maximum Jacq (Gramineae/Poaceae). Acta Agronômica 55: 62-66.

Dusi DMA and Williemse MTM (1999) Apomixis in Brachiaria decumbens Stapf.: gametophytic development and reproductive calendar. Acta Biologica Cracoviensa 41: 151-162.

Junqueira-Filho RG, Mendes-Bonato MB, Pagliarini MS, Bione NCP, Valle CB and Penteado MIO (2003) Absence of microspore polarity, symmetric divisions and pollen cell fate in Brachiaria decumbens (Gramineae). Genome 46: 83-86.

Lutts S, Ndikumana J and Louant BP (1991) Fertility of Brachiaria ruziziensis in interspecific crosses with Brachiaria decumbens and Brachiaria brizantha: meiotic behavior, pollen viability and seed set. Euphytica 57: 267-274.

Lutts S, Ndikumana J and Louant BP (1994) Male and female sporogenesis and gametogenesis in apomictic Brachiaria brizantha, Brachiaria decumbens and F1 hybrids with sexual colchicine induced tetraploid Brachiaria ruziziensis. Euphytica 78: $19-25$.
Mendes-Bonato AB, Pagliarini MS, Forli CB, Silva N and Valle CB (2001a) Meiotic instability in invader plants of signal grass Brachiaria decumbens Stapf (Gramineae). Acta Scientiarum 23: $619-625$.

Mendes-Bonato AB, Pagliarini MS, Penteado MIO and Valle CB (2001b) Archeosporial syncytes restricted to male flowers in a hexaploid accession of Brachiaria brizantha (Hochst.) Stapf (Gramineae). The Nucleus 44: 137-140.

Mendes-Bonato AB, Pagliarini MS, Forli CB, Valle CB and Penteado MIO (2002a) Chromosome number and microsporogenesis in Brachiaria brizantha (Gramineae). Euphytica 125: 419-425.

Mendes-Bonato AB, Junqueira-Filho RG, Pagliarini MS, Valle CB and Penteado MIO (2002b) Unusual cytological patterns of microsporogenesis in Brachiaria decumbens: abnormalities in spindle and defective cytokinesis causing precocious cellularization. Cell Biological International 26: 641-646.

Penteado MIO, Santos ACM, Rodrigues IF, Valle CB, Seixas MAC and Esteves A (2000) Determinação de ploidia e avaliação da quantidade de DNA total em diferentes espécies do gênero Brachiaria. Embrapa Gado de Corte, Campo Grande, 32p. (Boletim de Pesquisa, 11).

Ramsey J and Schemske DW (2002) Neopolyploid in flowering plants. Annual Review of Ecology and Systematics 33: 589-631.

Renvoize SA, Clayton WD and Kabuye CHS (1996) Morphology, taxonomy, and natural distribution of Brachiaria (Trin.) Griseb. In Miles JW, Maass BL and Valle CB (ed) The biology, agronomy, and improvement of Brachiaria. CIAT, Cali, p. $1-15$.

Crop Breeding and Applied Biotechnology 11: 43-49, 2011 
Risso-Pascotto C, Mendes-Bonato AB, Pagliarini MS and Valle CB (2003a) Comportamento citológico atípico durante a microsporogênese em Brachiaria ruziziensis e $B$. decumbens. Embrapa Gado de Corte, Campo Grande, 29p. (Boletim de Pesquisa e Desenvolvimento, 16).

Risso-Pascotto C, Pagliarini MS and Valle CB (2003b) A mutation in the spindle checkpoint arresting meiosis II in Brachiaria ruziziensis. Genome 46: 724-728.

Risso-Pascotto C, Pagliarini MS, Valle CB and Mendes-Bonato AB (2003c) Chromosome number and microsporogenesis in a pentaploid accession of Brachiaria brizantha (Gramineae). Plant Breeding 122: 136-140.

Risso-Pascotto C, Pagliarini MS, Valle CB and Jank L (2004) Asynchronous meiosis in an interspecific hybrid of Brachiaria ruziziensis and B. brizantha. Plant Cell Reports 23: 304-310.

Risso-Pascotto C, Pagliarini MS and Valle CB (2005) Multiples spindles and cellularization during microsporogenesis in an artificially induced tetraploid accession of Brachiaria ruziziensis (Gramineae). Plant Cell Report 23: 522-527.

Schifino MT and Moraes-Fernandes MIB (1986) Cytological comparison of diploid and autotetraploid Trifolium riograndense Burkart. Revista Brasileira de Genética 4: 637-643.

Schifino MT and Moraes-Fernandes MIB (1987) Induction of polyploidy and cytological characterization of autotetraploids of Trifolium riograndense Burkart (Leguminosae). Euphytica 36: $863-872$.

Simioni C, Schifino-Wittmann MT, Dall'Agnol M and Guerra D (2004) Selection for increasing $2 n$ gamete production in red clover. Crop Breeding and Applied Biotechnology 4: 477483.
Simioni C, Schifino-Wittmann MT and Dall' Agnol M (2006) Sexual polyploidization in red clover. Scientia Agricola 23: 26-31.

Simioni C and Valle CB (2009) Chromosome duplication in Brachiaria (A. Rich.) Stapf allows intraespecific crosses. Crop Breeding and Applied Biotechnology 9: 328-334.

Utsunomiya KS, Pagliarini MS and Valle CB (2005) Microsporogenesis in tetraploid accessions of Brachiaria nigropedata (Ficalho and Hiern) Stapf (Gramineae). Biocell 29: 295-301.

Valle CB (1990) Coleção de germoplasma de espécies de Brachiaria no CIAT: estudos básicos visando ao melhoramento genético. Embrapa Gado de Corte, Campo Grande, 33p. (Documentos, 46).

Valle CB and Savidan YH (1996) Genetics, cytogenetics and reproductive biology of Brachiaria. In Miles JM, Maass BC and Valle CB (ed) The biology, agronomy, and improvement of Brachiaria. CIAT, Cali, p. 147-163.

Valle CB, Simioni C, Resende RMS and Jank L (2008) Melhoramento genético de Brachiaria. In Resende RMS, Valle CB and Jank L (eds.) Melhoramento de forrageiras tropicais. Embrapa Gado de Corte, Campo Grande, p. 13-53.

Valle CB and Pagliarini MS (2009) Biology, cytogenetics, and breeding of Brachiaria. In Singh RJ (ed) Genetics resources, chromosome engineering, and crop improvement. CRC Press, Boca Raton, p. 103-151.

Young BA, Sherwood RT and Bashaw EC (1979) Cleared-pistil and thick-sectioning techniques for detecting aposporous apomixis in grasses. Canadian Journal Botanical 57: 1668-1672. 